
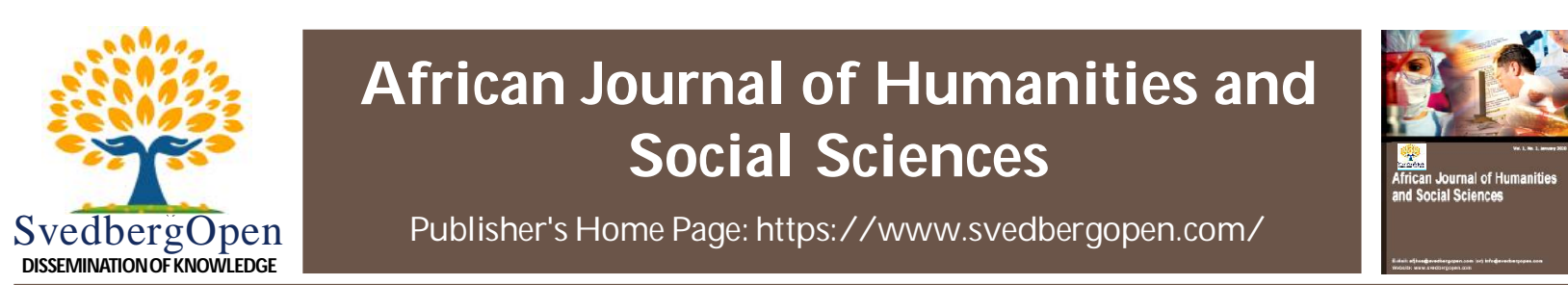

Research Paper

O pen A ccess

\title{
Violence Against Women in India: An Intersectional Approach to Human Rights $^{\#}$
}

\author{
Simant Shankar Bharti ${ }^{*}$ \\ ${ }^{1}$ Faculty of Political Science and International Studies, University of Warsaw, Poland. E-mail: s.bharti@uw.edu.pl
}

\section{Article Info}

Volume 1, Issue 1, August 2021

Received : 22 February 2021

Accepted : 10 July 2021

Published : 05 August 2021

doi: 10.51483/AFJHSS.1.1.2021.16-22

\begin{abstract}
Violence is physical and mental harassment that manifests in the forms of torture, harm, untouchably, insult, abuses, brutality, and many times in subtle forms. Women are generally suffered from this kind of violence not only in India and also in the entire world albeit reasons and forms of violence differ from regions to regions. The intersectional approach suggests that we will have to look at multiple forms of oppression and treat women as a heterogeneous category where factors like caste, class, region, locality, and language, and many others affects women in different ways and there is no single or only one form of oppression. For instance, the problem of Dalit women is completely different from upper-caste women. There is a tendency to treat women as a homogenous category and oversimplifying their oppression as something which affects all women across caste and class in the same manner. The rationale for such commonsense makes only sense when we consider women in relation to men as a whole. This reductionist approach to the question of women's oppression which ignores internal differences leads to later marginalization of marginalized among women and also creates new forms of discrimination and hierarchies which ultimately affects the lower strata of women and keeps their problem unheard and unanswered. Likewise, this paper explores all these aspects.
\end{abstract}

Keywords: Violence against women, Domestic-violence, India, Human-trafficking, Social work

(C) 2021 Simant Shankar Bharti. This is an open access article under the CC BY license (https: //creativecommons.org/licenses/by/4.0/), which permits unrestricted use, distribution, and reproduction in any medium, provided you give appropriate credit to the original author(s) and the source, provide a link to the Creative Commons license, and indicate if changes were made.

\section{Introduction}

Violence is physical and mental harassment, which manifests in the forms of torture, harm, untouchability, insult, abuses, brutality, and many times in subtle forms. Women are generally suffering from this kind of violence not only in India and in the entire world albeit reasons and forms of violence differ from regions to regions and

\footnotetext{
* Corresponding author: Simant Shankar Bharti, Doctoral Candidate at Faculty of Political Science and International Studies, University of Warsaw, Warsaw, Poland. E-mail: s.bharti@uw.edu.pl
}

\footnotetext{
\# This paper presented at Global Conference on Indian Diaspora Studies and Policies, October 5-7, 2017 - ISS, The Hague: International Institute of Social Studies, The Hague, Netherlands Volume: GCIDS2017.
}

2789-3413/@ 2021. Simant Shankar Bharti. This is an open access article distributed under the Creative Commons Attribution License, which permits unrestricted use, distribution, and reproduction in any medium, provided the original work is properly cited. 
countries to countries. Women are the victim of structural violence, which is not peculiar to Indian society only, and there are instances even in developed countries where gender justice has not fully achieved despite so many years of struggle for dignity and rights of women as a whole. Although women as a whole are oppressed vis-a-vis men in order to find out the holistic understanding of women subjugation we cannot take women as a homogenous category in which all women are equally oppressed. The intersectional approach suggests that we will have to look at multiple forms of oppression and treat women as a heterogeneous category where factors are focusing on caste, class, region, locality, and language and many others affect women in different ways and there is no single or only one form of oppression. For instance, the problem of Dalit (down-trodden) women is completely different from upper-caste women.

According to United Nations, Human rights "Human rights are rights inherent to all human beings, whatever our nationality, place of residence, sex, national or ethnic origin, color, religion, language, or any other status. We are all equally entitled to our human rights without discrimination. These rights are all interrelated, interdependent, and indivisible."

The thrust of women's liberation is to recognize them as human being worthy of equal respect and dignity, which has been denied in history and the so-called modern era. "Equality of rights for women is a basic principle of the United Nations". The Preamble to the Charter of the United Nations sets a central goal as "faith in fundamental human rights, in the dignity and worth of the human person, in the equal rights of men and women". ii

The United Nations Convention on the Elimination of All Forms of Discriminations Against Women (CEDAW) in 1976 focuses on non-discrimination, sex stereotypes, sex trafficking, also focuses on women's rights in the public sphere with an emphasis on political life, representation, and rights to nationality. This convention also described the economic and social rights of women, particularly focusing on education, employment, and health and included the special protections for rural women and the problems they face.

Though, this paper focuses on the violence against women in developing country especially issues in India. This issue for the selection of studies because during the Master's degree in Social Work's fieldwork practicum as an intern in the Gender Resource Center, Delhi and he actively participated in legal counseling for the women. During this fieldwork he observed women as one of the most disadvantaged groups and the way in which they are facing discrimination at every step of life and suffering from domestic violence even in the national capital of India, then one can imagine the condition of women in rural India where patriarchy is so entrenched.

\section{Methodology}

During an internship at Gender Recourse Centre (GRC), Delhi as a Social Work trainee on behalf of the Department of Social Work, University of Delhi. The researcher was the part of Legal Counselling Session at GRC every Thursday. He also covered more than 100 cases as well as reporting these cases to the agency and as the role of non-participant observant. The methodology selected for the study is Critical Discourse Analysis (CDA) and it is manifested relations between discourse and knowledge. "The philosophical inquiry, developed in epistemology, focuses on fundamental issues of the nature of knowledge, traditionally defined as 'justified true beliefs' and for a selection of work in epistemology where this concept is discussed".iii

In this research, the researcher criticized the violence against women in India under this counselling session and group counseling between both parties. According to Van Dijk T A, knowledge is acquired, shared, used by people in interaction, as well as by groups, institutions, and organizations. This methodology accepted discourse at legal counselling sessions as forms of social interaction. During the interaction; he mentioned and followed the principle of case studyexample; the principle of non-judgmental attitude, the principle of client's, self-determination, the principle of a meaningful relationship, the principle of controlled emotional involvement, and the principle of confidentiality.

\footnotetext{
Online web accessed http://www.ohchr.org/EN/Issues/Pages/WhatareHumanRights.aspx

ii Online web accessed http://www.un.org/womenwatch/daw/cedaw/history.htm

iii Van Dijk, T.A. (2003) The Discourse-Knowledge Interface. In: Weiss G., and Wodak R. (eds.) Critical Discourse Analysis. pp. 85-109. Palgrave Macmillan, London.
} 


\section{Violence Against Women in India: Focused Issues}

The question before us is why despite such omnipresent nature of violence against women in different forms has not led to moral outrage against such injustice. Why violence has become part of normal life and not worthy of even serious debates and discussion on a larger platform? Here are some reasons:

1) Believe in Natural Superiority and Hierarchy: The man dominated Indian society believes that women are mothers of humanity so, for the establishment of a good relation, sexes are one of the major foundations for the development of good relations between men and women. ${ }^{\text {iv }}$ Man has rights on their wife and both made for each other but all the decisions imposed especially in the case of family planning. Therefore, it is affected mentality traditional values towards hierarchal relations all the decisions made by male superiority and female subordination. However, women are also must be granted equal status in all forms of decision and society must be based on equal human relations. According to John Locke "Natural dependency for women is a social and economic dependence through the lack of property rights for a woman" (Sydie, 2011)

2) Social Condition: According to the feminist discourse 'women' are describing as different not only in sex term but as the gender that most important factors which depend on socially and culturally. ${ }^{\mathrm{v}}$ Therefore, Indian society discriminated for the socialization between boys and girls from birth to adulthood. They treated their child differently from childhood and girls were not allowed equally with boys, e.g., girls have not a choice for any kind of decision that is only decided by parents, whatever they do, is the only choice for them, so it is the major foundation of violence in rural areas well as in cities.

3) Inequality of Women: From the feminist scripture 'Gender' is defined as the socio-cultural or economic role of men and women, but as a biological term, their sexual orientation defines as male and female. Therefore, 'Inequality of women' means discrimination against women based upon sex and the ground of discrimination we can see also in the $21^{\text {st }}$ century in India. The Indian society still wants their child as the first choice is 'boy' and it is also leading to the major inequality of women so the state of Haryana is the most suitable example of the lowest sex ratio in India. The traditional Indian society is treating women as weaker sections in India actually in the male-dominated society is defining gender, as the role of power and man are considered to be superior (Borgohain, 1999; and Das, 2003).

\subsection{Types of Women Exploitation}

a) Cruelty by the Husband: This is the main foundation of the domestic violence against women laid by their husband's verbal threats of abuse and physical attack. After unlawful harassment, women started to commit suicide, most of the time they face serious injury to limbs and danger to life as well as regular health issues related to mental and physical problems. The death due to the dowry system and the burning of married women is a common phenomenon of cruelty on the side of husbands and their relatives in India.

b) Molestation: On December 31, 2016, Bangalore city of India witnessed the mass molestation of women and it was an occasion of New Year's Eve party. However, in Bangalore city it was a big shameful incident apart from this they faced these kinds of an incident in daily life e.g., bus, etc.

c) Kidnapping: The kidnapping of women created the major issues combined from it e.g., for marriage, rape, and human trafficking.

d) Abduction: Abduction is specially used for the kidnapping of the bride for the forced marriage.

e) Rape: Rape is forcefully and unwanted sexual intercourse and women facing this not only in India but also all over the world. However, from the last few decades, the rape percentage increased especially in big cities and Delhi gained its reputation as the rape city. On December 16, 2012, the Delhi rape case incident was a major object of brutal force.

f) Sexual Harassment: It is also an unwanted sexual contact of women by men and women are facing it in their daily life e.g., office, public transport, and some other places (Burgess, 1996).

\footnotetext{
iv Montagu, A. (1952). The Natural Superiority of Women, 238-248. Macmillan New York.

${ }^{v}$ Hooks, B. (2000). Feminist Theory: From Margins to Center. $2^{\text {nd }}$ edition. London: Pluto Press.
} 


\subsection{Effect of Violence on Women}

i) Psychological Effect: After the regular impact of violence, it affects women as mentally disturbance from stress, anxiety, anger, and depression.

ii) Diminished Value of Life: Women have been always considering lower strata in society and they never been counted as the main decision-maker.

iii) Loss of Potential: After a regular course of violence, they have become physically weaker and at risk of illness.

iv) Family Disruption: Due to abusive, physical, and mental violence, it resulted in family disruption. In most of the case, children have also been affected.

v) Economic Loss: Due to the effect of violence on women, they lost their jobs and loss of work productivities.

vi) Social Disruption: An isolated woman is also deprived of supports from society and she is unable to get access to the social environment.

\subsection{Fact and Figure}

i) Femicide: It is the systematic killing of women and girls in the context of the extreme level of torture, cruelty, and sexual violence. In Guatemala, two women are murdered, on average, each day but in India, 8,093 cases of dowry-related death were reported in 2007 and an unknown number of murders of women and young girls were falsely labelled 'suicides' or 'accidents'.

ii) Violence: Worldwide up to 50\% of sexual assaults are committed against girls under 16 and an estimated 150 million girls under the age of 18 years suffered some forms of sexual violence in 2002 alone.

iii) Harmful Practices: Approximately 130 million girls and women in the world have experienced female genital mutilation/cutting, with more than 3 million girls in Africa annually at risk of the practice.

\subsection{Trafficking}

i) Women and girls are $8 \%$ of the estimated 800,000 people trafficked across national borders annually, with the majority (79\%) trafficked for sexual exploitation. Within countries, many more women and girls are trafficked, often for purposes of sexual exploitation or domestic servitude. ${ }^{\mathrm{vi}}$

ii) A study in Europe found that $60 \%$ of trafficked women had experienced physical and/or sexual violence before being trafficked, pointing to gender-based violence as a push factor in the trafficking of women. vii $^{\text {vi }}$

\subsection{Sexual Harassment}

i) Between 40 and $50 \%$ of women in the European Union, countries experience unwanted sexual advances, physical contact, or other forms of sexual harassment at work.

ii) Across Asia, studies in Japan, Malaysia, the Philippines, and South Korea show that 30 to $40 \%$ of women suffer workplace sexual harassment. .iii $^{\text {Pin }}$

\subsection{Rape in the Context of Conflict}

i) Conservative estimates suggest that 20,000 to 50,000 women were raped during the 1992-1995 war in Bosnia and Herzegovina, while approximately 250,000 to 500,000 women and girls were targeted in the 1994 Rwandan genocide. ${ }^{\text {ix }}$

ii) Between 50,000 and 64,000 women in camps for internally displaced people in Sierra Leone were sexually assaulted by combatants between 1991 and $2001 .^{x}$

\footnotetext{
vi Online web accessed. http://www.endvawnow.org/en/articles/299-fast-facts-statistics-on-violence-against-women-and-girls-.html

vii Loc. Cit.

viii Loc. Cit.

ix Online web accessed http://www.endvawnow.org/en/articles/299-fast-facts-statistics-on-violence-against-women-and-girls-.html

${ }^{x}$ Ibid.
} 


\section{Forms of Violence in India}

1) Rape: The most impacting factor and issues concerning the respect of the opposite gender by the male society.

2) Sexual Domestic Violence: Unwanted and forceful sex is the most effective violence in the case of a marital relationship.

3) Patriarchal mindset of society.

4) Dowry related Murder and Bride Burning: It is another form of violence that is faced by women of low or middle-class families after marriage in both rural and urban areas. Groom's family is involved in the bride burning in case of lack of fulfiled dowry demand and in 2005, according to the Indian National Crime Bureau reports around 6,787 dowry death cases were registered in India.

5) Early Marriage: According to the United Nation's Population Funds "early marriage is a violation of human rights and despite laws", it is still being practiced in developing countries. One in every three girls is married before reaching the age of 18 and one in nine is married under the age of 15. ${ }^{\mathrm{xi}}$ Most of them have been observed in India and great numbers of child marriage cases have been registered in Bihar and Rajasthan.

6) Femicide: Based on sex-selective abortions are another form of femicide and it is a more leading problem in India e.g., Haryana is one of the Indian states and the decline in sex ratio becomes a problematic situation for not only the state government but also the central government. Recently, the Modi government has launched 'Beti Bachao, Beti Padhao' (Save the daughter and teach the daughter) campaign especially addressing this problem.

7) Female Genital Cutting

8) Honor Killing: this is the most prominent issue in Indian society, especially in districts of Haryana and love is a crime for these communities.

9) Human Trafficking

10) Violence against Women at Work (Sexual harassment at the workplace).

11) Gender discrimination in the labour market: unequal distribution of wages and responsibility.

12) Less political representation: In the general assembly election in 2014 and their representation was less than $10 \%$.

13) Inadequate Nutrition: Especially lover middle class women suffering this kind of problem and lack of proper diet, women combat from life and death at the time of delivery.

14) Status of widows: The Widows are considered worthless and face many types of restrictions even in daily conduct (The Culture-Ist, 2014; Afsharipour, 1999; and Maan, 2008).

\section{Violence Against Women: Feminist Discourse}

The question 'Violence against women' first time raised in the context of the political domain by feminists of the second wave movement of women. The feminist thinker around the world, they distinguished between direct violence and structural violence. In both forms of violence, they do suffer from different forms of violence and the patriarchal setup of the society is more responsible for the pathetic conditions of women especially in the case of India. According to Brigitte Schwab, 'Every man is seen as a potential perpetrator of violence against women' (Schwab, 2017).

In the last few decades, situations are becoming more apathetic towards violence against women in India. According to statistics of the National Crimes Record Bureau (NCRB, 2014) is showing that a horrific figure in 3, 37,922 total cases of crime against women being reported in India, an increase of $9.2 \%$ from the previous year and $58.2 \%$ from the year 2010 . Cases of cruelty by a husband or his relatives (36.4\%), assault with intent to outrage modesty ( $24.3 \%)$, kidnapping and abduction $(17.0 \%)$ and rape $(10.9 \%)$ are the main crimes reported. ${ }^{\text {xii }}$ There are just a few pictures of violence but there are many causes, which are happening every day, and everywhere in India that is not registered.

xi Online web accessed http://www.unfpa.org/child-marriage

xii Online web accessed http://discoversociety.org/2016/03/01/feminist-responses-to-violence-against-women-in-india/ 
According to Indian feminist discourse, situations are more pathetic in the case of Dalit women and they are not only facing violence from the upper caste of the society even they are also facing dominance and deviant behavior of their husbands in the domestic premises. After the increasing rate of violence not only on the ground of castes, classes, and religions, but it also goes beyond the intolerant behavior of the intersectional level of violence then the Indian feminist movement came into light in the 1970s. After the long battle of the feminist movement in India, the government has brought laws for men, but the feminists allege that this law imposed by the patriarchal society of India, and is not enough and unable to give justice to women. After the brutal Delhi rape case, 2012, the feminist movement laid in a very ironical way after that finally government, for the first time, amended its outdated rape and sexual assault laws in the Criminal Law (Amendment) Act, 2013. Nishi Mitra quoted in her article "feminists are now forced to rethink their strategies, as the law and criminal justice system in India have failed to arrest the problem of spiraling violence against women." (Mitra, Discover Society, 2016)

\section{Intersectional Approach to Human Rights}

There is a tendency to treat women as a homogenous category and oversimplifying their oppression as something that affects all women across castes and classes in the same manner. The rationale for such commonsense makes only sense when we consider women in relation to men as a whole. This reductionist approach to the question of women's oppression which ignores internal differences leads to later marginalization of marginalized among women and also creates new forms of discrimination and hierarchies that ultimately affect the lower strata of women and keep their problem unheard and unanswered. Keeping this intersectional approach in the mind, the central idea of the paper is to pay attention to violence against women in India. In the last, few decades' violence against women shaped into intersectional in the social context to the analysis of gender issues in India. Women are facing violence not only in few castes and in religions but it has changed in every section of the society in rural and urban India e.g., class - elite class and lower-middle class, caste - upper caste, middle caste, and lower caste (Das, 2005).

The level of violence seems to be visibly different in each class and caste of Indian society, such as in the urban family the level of violence is more seen as the mental violence, however on the other hand, in the rural family, the level of violence is fully aggressive and violent. However, if you talk of caste, here, too the level of violence is different. Especially in higher castes and lower-middle castes, the level of violence is the combination of mental violence and physical torture or in other words violence. However, in most women, particularly in the women of lower caste or downtrodden castes especially the status of Dalit women is a serious victim of violence. Because they have considered being from lower castes among the castes and they have to suffer from violence in the home as well as higher castes. In a state of being Dalit women, they have to suffer from more torture and violence. The intersectional approach is not only indicating here level of violence in a different section of the society they are also facing the violence of racial discrimination in the context of the selection of the brides. If a girl is dark or black skins color, their family member faces difficulty to find a groom for them. Even if she got married to the white boy, their family in law has done psychological violence (Das, 2005).

\section{Conclusion}

The violence against women in India is still a genuine issue and there requires more effort towards changing people's perception regarding women for equal treatment. It is also an important field for scientific inquiry and totally removal of the violence from society and treated with women as the homogenous category for proper address to human rights. There are many common violence faces for women at the intersectional approach to human rights and in every section of the society, only women are facing violence, but the nature of violence changes in every section. Women are suffering from gender discrimination which they face from their birth and it continues until their death. There is illiteracy, the lack of proper education, responsible for household works; rape, sexual harassment at the workplace, these are some big issues for women in India. They are also facing many challenges in different forms, like the patriarchy mindset of society, economic, social security, and political representation. Women have just $10 \%$ representation in the parliament due to this they are unable to raise the voice and make a law.

There is a need for a Self-Help Group (SHG) that can help women in the process of empowerment. Because it's a not only rural and urban-based financial institution but a multidimensional one. Though, a "legal awareness session and camps' would be a great initiative for the cop-up mechanism. Because there are certain values included in Indian women since their birth which it projects them as 'Sati Savitri' and worship of their husband that considered 'Pati Parmeshwar'. This is also one of the founding patriarchal practice that leads to domestic violence." But, SHG also arranges adult literacy classes and legal session to educate them about domestic violence (Bharti, 2016). Mitigate those challenges are 
community needs and Corporate Social Responsibility (CSR) initiatives can address those issues through CSR policies by corporates houses with their stakeholders (Bharti and Sarkar, 2016).

\section{References}

The Culture-Ist. (2014). 12 Gender Issues Affecting Women Around the World.

Afsharipour, A. (1999). Empowering Ourselves: The Role of Women's NGOs in the Enforcement of the Women's. Columbia Law Review, 99(1), 129-172.

Bharti, S. S. (2016). Role of SHG's in Women Empowerment. Uttarvarta, 1(6), 43-48. available at SSRN: https:// ssrn.com/abstract $=3704079$

Bharti, S.S., and Sarkar, S., (2016). Tracing The Gap Between Corporate Social Responsibility (CSR) Initiatives and Community Needs. Uttarvarta, 1(7), 43-48. available at SSRN: https://ssrn.com/abstract=3704077

Borgohain, B. (1999). Human Rights-Social Justice and Political Challenges. New Delhi: Sage Publication.

Burgess, N. A. (1996). Understanding Violence Against Women. Washington, D.C.: National Academy Press.

Das, J. K. (2003). Reflections on Human Rights and the Position of Indian Women. The Indian Journal of Political Science, 64(3/4), 203-220.

Das, S. P. (2005). Human Rights : A Gender Perspective. The Indian Journal of Political Science, 66(4), 755-772.

Hooks, B. (2000). Feminist Theory: From Margins to Center, $2^{\text {nd }}$ edition. London: Pluto Press.

Kolnai, A. (1971). The Concept of Hierarchy. Philosophy. Cambridge University Press on behalf of Royal Institute of Philosophy. 46(177), 203-221.

Maan, I.S. (2008). Globalization : Its Impact on Women Human Rights in India. The Indian Journal of Political Science, 69(2), 371-379.

Mitra, N. (2016). Retrieved from Discover Society: http://discoversociety.org/2016/03/01/feminist-responses-toviolence-against-women-in-india/.March 01.

Mitra, N. (2001). Community Based Initiatives in the Struggle against Domestic Violence. The Indian Journal of Social Work, 62(3).

OHCHR. (2016). Convention on the Elimination of All Forms of Discrimination against Women. (n.d.). Retrieved April 2, 2016, from www.ohchr.org: http://http://www.ohchr.org/EN/Pages/Home.aspx

Schwab, B. (2017). The Feminist Discourse on Violence against Women. June 30. Retrieved from ECPR: https:// ecpr.eu/Filestore/PaperProposal/505709f7-a68f-4f95-afc5-a1e09732292b.pdf

Sydie, R. (2011). Natural Women, Cultured Men: A Feminist Perspective on Sociological Theory. British Columbia: UBC Press.

Tang, K.-1. (2004). Internationalizing Women's Struggle against Discrimination: The UN Women's Convention and the Optional Protocol. The British Journal of Social Work, 34(8), 1173-1188.

UN Women. (2000-09). Retrieved April 2, 2016, from http://www.unwomen.org/en: http://www.un.org/womenwatch/ daw/cedaw/history.htm

Venkateswaran, P. (1997). Women's Issues in Global Context: A Syllabus. Women's Studies Quarterly, 25(3/4), 225232. Teaching African Literatures in a Global Literary Economy, Fall-Winter.

Waseem Ahmad, S.M.A. (2006). Social Justice and the Constitution of India. The Indian Journal of Political Science, 67(4), 767-782.

White, K. (1985). Teaching about Women and Violence. Women's Studies Quarterly, 13(3/4), 23-26. Teaching about Women and Violence.

Cite this article as: Simant Shankar Bharti (2021). Violence against Women in India: An Intersectional A pproach to Human Rights. . A frican J ournal of H umanities and Social Sciences, 1(1), 16-22. doi: 10.51483/ A FJHSS.1.1.2021.16-22. 